Vol. 5 (1996): 567-576.

\title{
GIS analysis of change in an agricultural landscape in Central Finland
}

\author{
Riitta Ruuska \\ Department of Plant Production, P.O. Box 27, FIN-00014 University of Helsinki, Finland
}

Juha Helenius

Department of Applied Zoology, University of Helsinki, Present address: Department of Plant Production, P.O. Box 27, FIN-00014 University of Helsinki, Finland, e-mail: juha.helenius@ helsinki.fi

\begin{abstract}
Changes in landscape over a period of 50 years were analysed in a rural area of 324 ha in Central Finland. The data were digitized from aerial photographs of the National Land Survey taken in 1944, 1959, 1979 and 1991, and analysed with the IDRISI ${ }^{\mathrm{TM}}$ geographic information system (GIS). The average proportion of land in agricultural use in the sample area was $17.4 \%$.

The arable area declined from the maximum of 62.3 ha (1959) to 47.6 ha. The total length of linear landscape elements, predominantly ditch bank habitats, halved, from $876 \mathrm{~m} / \mathrm{ha}$ of field (1944) to $449 \mathrm{~m} / \mathrm{ha}$ by the end of the period. The average rate of loss of field boundary habitat was $9.1 \mathrm{~m} / \mathrm{ha} /$ year. At the same time, the Shannon-Weaver index of diversity of agricultural landscape elements dropped from 0.37 to 0.24 . The number of field parcels declined by $29 \%$, and the mean parcel size increased by $45 \%$, from 1.2 ha to 1.7 ha. The index value of the fractal dimension measuring the complexity of parcel shapes also fell, from 1.88 (1959) to 1.86 (1991).

The change in spatial structure reflects the intensification of farming in Finland. Biodiversity at ecosystem level has clearly declined. However, the implications for the agroecosystem and its sustainability are still unknown.
\end{abstract}

Key words: landscape ecology, land use change, GIS, agro-ecosystems, spatial patterns

\section{Introduction}

Agricultural land use maintains particular kinds of landscape mosaics. Quantifying the pattern and dynamics of such mosaics is the first step in understanding the ecological, hydrological and biogeochemical processes taking place within the landscape.

Landscape ecology develops quantitative measurements relevant to ecological analysis (see, e.g. Cullinan and Thomas 1992). The landscape elements comprising the ecological infrastructure, e.g. field margins, forest islands and 


\section{AGRICULTURAL AND FOOD SCIENCE IN FINLAND}

Ruuska, R. \& Helenius, J. Analysis of agricultural landscape change

wetlands, are important habitats for natural flora and fauna (Bengtsson-Lindsjö et al. 1991). Linear landscape elements such as ditch banks can act as ecological corridors when they connect habitat patches to each other. In addition to their conservation value, field margins may serve as a habitat for natural enemies of pests and thus have a favourable effect on plant protection (Dennis and Fry 1992). The change, fragmentation and disappearance of natural habitats are claimed to be the main factors causing a decrease in biodiversity in the world (Angelstam 1992). In short, the quality of a habitat depends on its position in, and the quality of, the landscape mosaic itself.

The advent of computer aided technologies has made large-scale spatial analysis possible in landscape research. Remote-sensing material such as aerial photos and satellite images is used as a source of data in geographic information systems (GIS) for pattern mapping and dynamic analysis (Quattrochi and Pelletier 1991).

Technological progress has been rapid in agricultural production in Finland, and indeed the whole Western world, during the last few decades. Intensification of production through mechanization and the increasing use of chemicals has had a very visible impact on the agricultural landscape, and the areas used for agricultural production have become increasingly monotonous (e.g. Forman and Godron 1986). The sustainability of such a trend is widely questioned. In Finland, only $8 \%$ of the land area is used for agriculture and, hence, maintenance of diverse agricultural landscapes is of particular concern.

Our study examines changes in an agricultural landscape in Central Finland during the last 50 years; to our knowledge, no such study has been conducted anywhere in Finland before. Unpublished data are available from Korhonen (1995). We chose an intermediate spatial level to draw attention to the need to fill the gap between regional, political and local, farm-level, land-use planning. We tested the use of aerial photographs as a source and GIS as a tool in spatial analysis. The emphasis was on linear struc- tures as these effectively describe and quantify spatial pattern changes.

\section{Material and methods}

\section{Study area}

The landscape studied, a regular shaped land area of 324 ha selected at random, was located in Central Finland, in the municipality of Toivak$\mathrm{ka}\left(62^{\circ} 08^{\prime} \mathrm{N}, 26^{\circ} 05^{\prime} \mathrm{E}\right)$. The rectangular area is defined by the base map coordinates of the Finnish Grid x: 3451654; y: 6893156 (lower left corner) and $\mathrm{x}$ : $3453100 ; \mathrm{y}$ : 6895412 (upper right corner). The area is largely covered by forest. The main production sector is dairying, and the arable area is largely under grass crops and fodder cereals. A field survey was conducted in summer 1994 to establish the present stage of the landscape and to obtain some reference data to aid the interpretation of aerial photographs.

\section{Aerial photographs}

The aerial photographs, which cover the 47 years from 1944 to 1991, were obtained from the National Land Survey of Finland. They measured $30 \mathrm{~cm} \times 50 \mathrm{~cm}$ and were at 1:5000 scale. With the exception of the 1991 photograph, which was a false colour (infrared) copy, they were standard black and white photos. In a false colour photograph the vegetation is easier to identify from the colour; in black and white photographs the interpretation is based on grey-scale tones.

\section{Digitizing}

The aerial photographs, which were transformed into digital form using a Calcomp digitizing board and TOSCA ${ }^{\mathrm{TM}}$ software, were not geometrically corrected. We had six control points in the digitizing procedure. Residual errors of the 
Vol. 5 (1996): 567-576.

points as the Euclidean distance from the numerically entered coordinate to the best fit for the corresponding points digitized were used to produce residual mean squares (RMS, square roots of the mean of the sum of the squares of the residuals). The mean value of RMS was $9.7 \mathrm{~m}$ (range $9.0 \mathrm{~m}$ to $10.3 \mathrm{~m}$ ) and 9.4 (range 8.1 to 10.5 ) for length and area measurements, respectively. Given locational error of $0.5 \mathrm{~mm}$ or less on the map as acceptable, the critical RMS was $10 \mathrm{~m}$, a condition which was met in our procedure (Jones 1992). The landscape elements were digitized as lines, polygons and points according to the classification made for the landscape analysis. The classification included only those habitats which are relevant to an agricultural landscape.

The linear elements were digitized into two classes: ditch banks dividing parcels of arable land, and arable field borders adjoining to nonarable land. The linear elements represented actual field margins: for example, for a margin composed of a ditch bank, ditch and road verge, the ditch bank was digitized and the road verge was omitted.

All the areal elements were digitized as polygons. The field parcels within the agricultural land were digitized as polygons into a separate file. The point elements were barns. All the photographs were digitized separately in different files.

\section{GIS analysis}

The GIS package used was the PC-based, DOS program IDRISI ${ }^{\mathrm{TM}}$ (Eastman 1992). The rasterbased data structure supported by IDRISI ${ }^{\mathrm{TM}}$ consists of rows and columns which make up a matrix of pixels, all with a value. The raster data make it easier to analyse the map data and display the spatial characteristics of areas. For the map analysis the digitized vector files were converted into raster format images. The resolution of the images was $2 \mathrm{~m}$ and the coverage of the images $2272 \times 1426$ meters.
In IDRISI ${ }^{\mathrm{TM}}$ the separate files with the different landscape elements were recombined as one map for each year. The map images were then reclassified into appropriate classes. The final classification for the landscape elements was as follows:

Linear elements:

Dividing

Areal elements:

1. Main ditch

1. Arable field

2. Field ditch

2. Uncultivated field

3. Forested land

Bordering

1. Forest edge

4. Other land

5. Watercourse

2. Other land edge

3. Watercourse edge Point elements: barns

4. Road edge

5. Farm road edge

The variables measured by means of IDRISI $^{\mathrm{TM}}$ were the lengths of linear elements (m) and the areas of areal elements (ha). The linear elements were digitized as two-dimensional lines and, due to the raster format, were produced as chains of pixel units. Thus, the length of linear elements was calculated by dividing their area by two, which was the resolution of the grid map. We assume no systematic bias due to this approximation. The lengths and areas were calculated for each landscape class throughout the study period, and changes in the proportion of landscape elements were defined.

The number of field parcels was counted for each study year and the size of the parcels calculated. The change in the field size was described by various distribution parameters. The size of the field parcels was analysed statistically by comparing the averages and medians of the parcel size distribution curves. The statistical data were analysed using the non-parametric Kolmogorov-Smirnov test and the median test.

For the diversity analysis the width of linear elements was given an approximate value of 1 $\mathrm{m}$. Finnish legislation requires a width of $0.6 \mathrm{~m}$ for ordinary ditch banks, but they are wider for technical reasons in practice. As parameters for the diversity of the agricultural landscape structure, the diversity index and dominance within the fields were calculated (O'Neill et al. 1992, 


\section{AGRICULTURAL AND FOOD SCIENCE IN FINLAND}

Ruuska, R. \& Helenius, J. Analysis of agricultural landscape change

Kienast 1993). These were obtained by combining the areas of the linear field margin biotopes with the acreages of cultivated and uncultivated fields. The function used for diversity was the Shannon-Weaver diversity index $(\mathrm{H})$. (For the properties of H, see e.g. Krebs 1972 and May 1975.) This index based on the proportions of different cover types in the landscape and was calculated from the equation (1):

$\mathrm{H}=-\sum_{\mathrm{k}=1}^{\mathrm{m}}\left(\mathrm{P}_{\mathrm{k}}\right) \ln \left(\mathrm{P}_{\mathrm{k}}\right)$

where

$\mathrm{m}=$ the number of different landscape element classes

$P_{k}=$ the relative area of the class $k$

The maximum diversity was calculated from the equation (2):

$\mathrm{H}_{\max }=\ln (\mathrm{m})$

The dominance is obtained from the former indices from (3):

$$
\mathrm{D}=\frac{\mathrm{H}_{\max }-\mathrm{H}}{\mathrm{H}_{\max }}
$$

The value of dominance, which varies between zero and one, expresses the extent to which one of the landscape elements dominates the area.

The fractal dimension (d) was used to estimate the complexity of the landscape mosaic. It was calculated for field parcel patches as the slope for a log-log regression of area against perimeter (Lovejoy 1982, see also Kienast 1993):

$\ln S=d \ln \frac{P}{4}$

where

$\mathrm{S}=$ area of a patch (field parcel)

$\mathrm{P}=$ perimeter of a patch

$\mathrm{d}=$ fractal dimension

High values of the fractal dimension indicate a landscape composed of many patches with a complex and convoluted shape, whereas low values are typical of plane filling, with simple geometric patches (Kienast 1993).

\section{Results}

Marked changes in the landscape took place during the study period, as illustrated in Fig. 1, even though only minor changes occurred in the absolute areas of individual land-use classes. Three-quarters of the area was covered by forest, and one-fifth by agricultural fields. The area of uncultivated fields within the main class of 'agricultural fields' increased threefold, but this was at the expense of arable fields, which declined by approximately the same acreage (Table 1).

The quantity of linear landscape structures declined considerably as a whole but differences between the element classes were large. Changes were most rapid in the middle of the study period, between 1959 and 1979 (Fig. 2).

The total length of linear landscape elements declined from nearly $61 \mathrm{~km}$ (1959) to $32 \mathrm{~km}$ (1991). The total length of linear structures declined by more than $47.3 \%$ from 1959 to 1991 . It halved from $876 \mathrm{~m} / \mathrm{ha}$ of field (the peak value was in 1944, including arable and uncultivated classes) to $449 \mathrm{~m} / \mathrm{ha}$ by the end of the period. The average rate of loss of field boundary habitat was $9.1 \mathrm{~m} / \mathrm{ha} /$ year. At its fastest, the decline was $16.5 \mathrm{~m} / \mathrm{ha} /$ year, from 1959 to 1979 . The landscape element class 'Field ditch' had the biggest proportion of total length throughout the study period (Table 2).

Barns adjacent to fields were here regarded as point elements. The number of barns fell from 24 to six between 1944 and 1991 . The greatest change occurred between 1959 and 1979 (from 24 to 11 ), but there was no change between the first two study years.

Biotope diversity $(\mathrm{H})$ declined by $35 \%$ during the study period and dominance (D) increased correspondingly (Table 3 ). The value of 


\section{AGRICULTURAL AND FOOD SCIENCE IN FINLAND}

Vol. 5 (1996): 567-576.
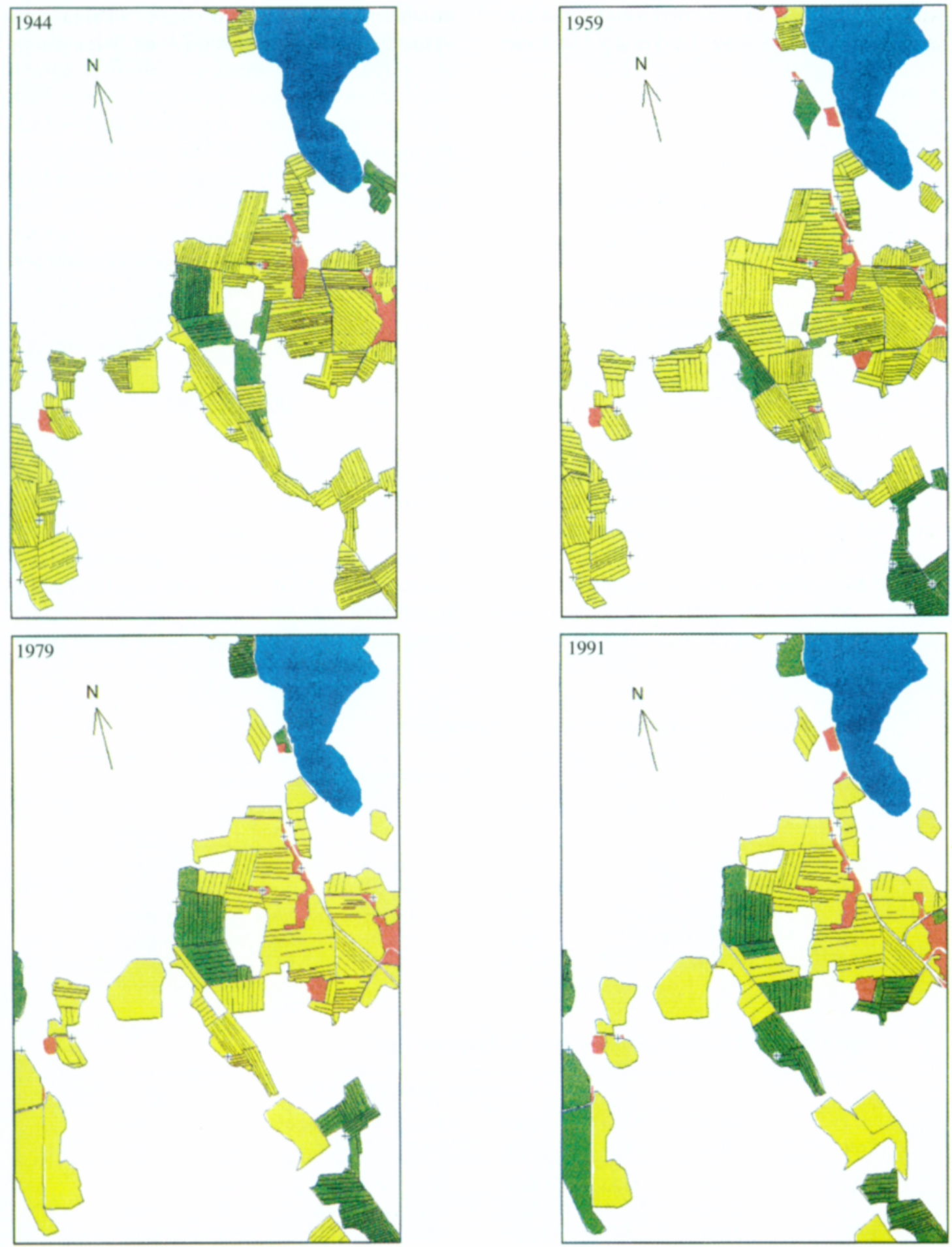

Fig. 1. GIS maps of change from 1944 to 1991 in linear (black lines) and areal (yellow: arable field; green: uncultivated field; blank: forested land; red: other land; blue: lake) landscape elements in the Toivakka study area. The maps cover an area of $1426 \mathrm{~m} \times 2272 \mathrm{~m}$. 


\section{AGRICULTURAL AND FOOD SCIENCE IN FINLAND}

Ruuska, R. \& Helenius, J. Analysis of agricultural landscape change

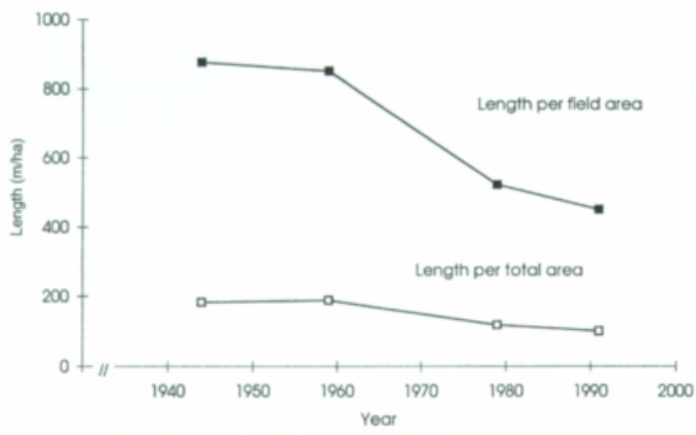

Fig. 2. Linear landscape elements: total length per field area and per total area (m/ha) from 1944 to 1991 in the study area. ha. The distribution curves of the field size are skewed to the left, especially for the first two study years. The number of small field parcels was high in those years but in the last study year, 1991, the parcels were distributed fairly evenly between the size classes. The mean field parcel size was significantly larger in 1991 than in 1959 (Kolmogorov-Smirnov two-sample test, $\mathrm{p}=0.0127$ ), as was the median parcel size (median test, $\mathrm{p}=0.023$, Tukey-like pairwise comparison) (Table 4).

\section{Discussion}

the fractal dimension was at its highest, 1.88 in 1959, and declined to 1.86 in 1991 (Table 3), implying that the field mosaic has become more geometric in shape during the last 30 years.

The mean size of the field parcels increased from 1.2 ha to 1.7 ha during the study period and the median changed from 0.93 ha to 1.62
The analysis showed clear changes in the landscape structure during the study period from the 1940 s to 1990 s, the trend being towards a less diverse, more coarse-grained agricultural landscape. This is seen most clearly in the decline in the number of linear landscape elements over time, but also in the increase in the size of fields.

Table 1. Total areas (ha) by classes of areal landscape elements.

\begin{tabular}{lccccc}
\hline \multicolumn{6}{c}{ Landscape element area (ha) } \\
Year & $\begin{array}{c}\text { Arable } \\
\text { field }\end{array}$ & $\begin{array}{c}\text { Uncultivated } \\
\text { field }\end{array}$ & Forest & $\begin{array}{c}\text { Other } \\
\text { land }\end{array}$ & $\begin{array}{c}\text { Water- } \\
\text { course }\end{array}$ \\
\hline 1944 & 59.5 & 8.1 & 236.0 & 3.2 & 17.2 \\
1959 & 62.3 & 9.3 & 231.8 & 3.7 & 16.8 \\
1979 & 56.3 & 16.3 & 231.4 & 3.5 & 16.6 \\
1991 & 47.6 & 23.9 & 231.7 & 4.2 & 16.7 \\
\hline
\end{tabular}

Table 2. Total lengths ( $\mathrm{m}$ ) by classes of linear landscape elements.

\begin{tabular}{lcrrrrrr}
\hline \multicolumn{7}{c}{ Landscape element length $(\mathrm{m})$} \\
Year & $\begin{array}{l}\text { Field } \\
\text { ditch }\end{array}$ & $\begin{array}{r}\text { Main } \\
\text { ditch }\end{array}$ & $\begin{array}{c}\text { Forest } \\
\text { edge }\end{array}$ & $\begin{array}{c}\text { Other } \\
\text { land }\end{array}$ & $\begin{array}{c}\text { Watercourse } \\
\text { edge }\end{array}$ & $\begin{array}{r}\text { Road } \\
\text { edge }\end{array}$ & $\begin{array}{c}\text { Field road } \\
\text { edge }\end{array}$ \\
\hline 1944 & 43984 & 1120 & 11438 & 1488 & 244 & 490 & 426 \\
1959 & 44382 & 1194 & 10618 & 2056 & 240 & 1536 & 904 \\
1979 & 20740 & 552 & 11434 & 1962 & 312 & 1592 & 1282 \\
1991 & 15798 & 804 & 10722 & 2108 & 224 & 2164 & 312 \\
\hline
\end{tabular}


Vol. 5 (1996): 567-576.

The decline in the number of linear elements is largely explained by the replacement of open field ditches by sub-surface drainage which has taken place throughout the country during the last decades. The proportion of field submitted to sub-surface drainage rose from $5 \%$ to almost $50 \%$ in Finland during the study period. In the province of Central Finland the change was from $2 \%$ to one-third of the arable area (Maatilahallitus 1916, 1923, 1932, 1947, 1954, 1963, 1973, 1981, 1991, Maa- ja metsätalousministeriö 1994).

The decrease in the length of open field ditches in relation to field area was $426 \mathrm{~m} / \mathrm{ha}$ in the study area. This is somewhat less than that estimated by Helenius et al. (1995), according to whom sub-surface drainage has replaced, on average, 500 $\mathrm{m} / \mathrm{ha}$ of open ditches at the national level.

The linear landscape elements can be reclassified as those bordering or dividing a patch of fields. Field-dividing elements, e.g. open ditches, are ecologically important because they may act as corridors in the landscape. In the study area, $63 \%$ of these field-dividing biotopes dis- appeared. At the same time the proportion of linear elements bordering fields relative to all linear elements doubled. These forest edges, road edges and other field margins, which form the ecotones of agroecosystems, have many functions. As refuges for organisms, they either hinder (e.g. Mader 1984) or enhance movement of the organisms along and across the element, and they act as biophysical buffer zones against nutrient fluxes from one ecosystem to another.

The values of landscape pattern indices, diversity and dominance, disminished within the fields. The decline was entirely due to reduced homogenity in the proportions of land use classes, as no classes were lost. The indices are insensitive to any change that retains the ratios between landscape elements, and they handle all the elements as equally important. Thus, the diversity index as such is not self-explanatory in measuring biotope diversity or the ability of the landscape to provide habitats and maintain populations within the landscape.

The decrease in the value of the fractal dimension is related to the change in the shape of

Table 3. Agricultural (within-field and field margin element classes) landscape pattern indices.

\begin{tabular}{lcccc}
\hline Year & Diversity H & $\begin{array}{c}\text { H/Hmax*, } \\
\%\end{array}$ & Dominance D & $\begin{array}{c}\text { Fractal d, } \\
(\text { s.e. })^{* *}\end{array}$ \\
\hline 1944 & 0.367 & 17.7 & 0.823 & $1.871(0.0084)$ \\
1959 & 0.368 & 17.7 & 0.823 & $1.877(0.0075)$ \\
1979 & 0.267 & 12.8 & 0.871 & $1.867(0.0081)$ \\
1991 & 0.239 & 11.5 & 0.885 & $1.865(0.0093)$ \\
\hline
\end{tabular}

${ }^{*}$ Hmax, maximum diversity for the eight landscape element types was 2.079

** Standard error of the fractal dimension $\mathrm{d}$.

Table 4. Number, mean size and size distribution of values for field parcels.

\begin{tabular}{llllcccc}
\hline Year & N & Total & Mean & Median & Maximum & Minimum & $\begin{array}{c}\text { Standard } \\
\text { deviation }\end{array}$ \\
\hline 1944 & 52 & 62.0 & 1.19 & 0.93 & 3.79 & 0.17 & 0.85 \\
1959 & 56 & 65.6 & 1.17 & 0.89 & 4.84 & 0.09 & 1.00 \\
1979 & 46 & 66.6 & 1.45 & 1.39 & 3.87 & 0.20 & 0.95 \\
1991 & 37 & 63.0 & 1.70 & 1.62 & 3.92 & 0.21 & 1.00 \\
\hline
\end{tabular}




\title{
AGRICULTURAL AND FOOD SCIENCE IN FINLAND
}

\author{
Ruuska, R. \& Helenius, J. Analysis of agricultural landscape change
}

field parcels rather than to the increase in the size of the parcels with the disappearance of open field ditches. Rationalization and mechanization of agriculture during the 1960's and 1970's resulted in larger and more geometric field parcels.

Clearly, landscape diversity began to decline after the 1950s in this agricultural area. From the agricultural statistics cited above, it is evident that the trend has been the same countrywide. The pace of change was most rapid between 1959 and 1979, since when it has slowed down. The change in the spatial structure also reflects changes in agricultural practices and the intensification of farming in Finland.

The loss of diversity suggests impaired ecological sustainability of agricultural production. Such a conclusion cannot, however be based on spatial analysis alone. Despite strict quality control, topographic sheets are only a sketch of real patterns and processes, and the ecological value of the elements depicted is often difficult to assess (Kienast 1993).

During the study period, technology and policy-driven changes in land use made rapid inroads in the agricultural sector. In the first years of the study period, new fields were cleared but towards the end an increasing number were taken out of the cultivation owing to restrictions on agricultural production. After years of succession, such abandoned fields lose their biodiversity and are lost to the overwhelming body of forests. This change reflects a nationwide trend in agricultural land use. The area of agricultural land was at its largest ( 2.7 mill. ha) in the early 1960 s, after which the area of uncultivated fields rose to $9 \%$ of the field area (Maatilahallitus 1916, 1923, 1932, 1947, 1954, 1963, 1973, 1981, 1991, Maa- ja metsätalousministeriö 1994).

In the future it will be worthwile to apply a similar approach that was used here to monitor landscape changes nationally. However, more accurate data on land use and crop rotation are needed to characterize the ecosystem-level functions and processes. Sustainable production could be defined and planned at the landscape level with the aid of GIS. It is particulary important to introduce an intermediate spatial level into land-use analysis and planning. This spatial level could well range from 'village' to small catchment. An ecologically meaningful level between single farm and county or region is currently lacking in land-use planning.

Acknowledgements. This study was funded by grant No. 5636 of the Research Council of Agriculture and Forestry, Academy of Finland. We would like to thank Aino-Maija Evers and the study group for constructive comments.

\section{References}

Angelstam, P. 1992. Conservation of communities importance of edges, surroundings and landscape mosaic structure. In: Hansson, L. (ed.). Ecological Principles of Nature Conservation, Applications in Temperate and Boreal Environments. Elsevier Applied Sciences, London. p. 9-70.

Bengtssön-Lindsjö, S., Ihse, M. \& Olsson, E.G.A. 1991. Landscape patterns and grassland plant species diversity in the 20th century. Ecological Bulletins 41: 388-396. Cullinan, V.I. \& Thomas, J.M. 1992. A comparison of quantitative methods for examining lanscape pattern and scale. Landscape Ecology 7: 211-227.

Dennis, P. \& Fry, G.L.A. 1992. Field margins: can they enhance natural enemy population densities and general arthropod diversity on farmland? Agriculture, Ecosystems and Environment 40: 95-115.
Eastman, J.R. 1992. IDRISI version 4.0. User's guide \& technical referece. Clark University, Graduate School of Geography. Worcester, USA. 213 p.

Forman, R.T.T. \& Godron, M. 1986. Landscape ecology. John Wiley \& Sons, New York. 619 p.

Helenius, J., Tuomola, S. \& Nummi, P. 1995. Viljelyympäristön muutosten vaikutus peltopyyn ravintoon. (Summary: Food availability for the grey partdridge in relation to changes in the arable environment). Suomen Riista 41: 42-52.

Jones, J. 1992. TOSCA Reference Quide, Version 1.0. Clark University, Worcester (USA). 42 p.

Kienast, F. 1993. Analysis of historical landscape patterns with a geographical information system - a methodological outline. Landscape Ecology 8: 103-118.

Korhonen, R. 1995. Keskisuomalaisen maatalousmaise- 
Vol. 5 (1996): 567-576.

man alue-ekologinen analyysi paikkatietojärjestelmăn avulla. (GIS analysis of an agricultural landscape in Central Finland). University of Helsinki, Department of Plant Production. 62 p. (Master's thesis, in Finnish).

Krebs, C.J. 1972. Ecology: the experimental analysis of distribution and abundance. Harper \& Row, New York. $694 \mathrm{p}$.

Lovejoy, S. 1982. Area-perimeter relation for rain and cloud areas. Science 216: 185-187.

Maa- ja metsätalousministeriö. 1994. Maatilatilastollinen vuosikirja 1994. Suomen virallinen tilasto. Maa- ja metsătalous 1994: 5. Helsinki.

Maatilahallitus. 1916. Suomen virallinen tilasto III, Maatalous, vol. 9. Helsinki. (in Finnish).

- 1923. Suomen virallinen tilasto III, Maatalous, vol. 17. Helsinki. (in Finnish).

- 1932. Suomen virallinen tilasto III, Maatalous, vol. 27. Helsinki. (in Finnish).

-1947. Suomen virallinen tilasto III, Maatalous, vol. 37A. Helsinki. (in Finnish).

- 1954. Suomen virallinen tilasto III, Maatalous, vol. 45/

1. Helsinki. (in Finnish).

- 1963. Suomen virallinen tilasto III, Maatalous, vol. 56.
Helsinki. (in Finnish).

- 1973. Suomen virallinen tilasto III, Maatalous, vol. 69. Helsinki. (in Finnish).

- 1981. Suomen virallinen tilasto III, Maatalous, vol. 79. Helsinki. (in Finnish).

- 1991. Maatilatilastollinen vuosikirja 1990. Suomen virallinen tilasto. Maa-ja metsătalous 1991:2. Helsinki. (in Finnish).

Mader, H.-J. 1984. Animal habitat isolation by roads and agricultural fields. Biolocial Conservation 29: 81-96.

May, R.M. 1975. Patterns of species abundance and diversity. In: Cody, M.L. \& Diamond, J.M. (eds.). Ecology and evolution of communities. Harvard University Press, Cambridge, Mass. p. 81-120.

O'Neill, R.V., Gardner, R.H. \& Turner, M.G. 1992. A hierarchical neutral model for landscape analysis. Landscape Ecology 7: 55-61.

Quattrochi, D.A. \& Pelletier, R.E. 1991. Remote sensing for analysis of landscapes: an introduction. In: Turner, M.G. \& Gardner, R.H. (eds.). Quantitative Methods in Landscape Ecology: The Analysis and Interpretation of Landscape Heterogenity. Ecological Studies 82. Springer-Verlag, New York. p. 51-76.

\title{
SELOSTUS
}

\section{Keskisuomalaisen maatalousmaiseman muutosten GIS-analyysi}

\author{
Riitta Ruuska ja Juha Helenius \\ Helsingin yliopisto
}

Viljely-ympäristön maisemarakenteen muutosta 1940-luvulta 1990-luvulle tutkittiin ilmavalokuva-aineistosta paikkatietojärjestelmän avulla. Eri maisemaelementtien koko, muoto ja keskinäiset suhteet muodostavat alueen maisemarakenteen, jota voidaan tulkita visuaaliselta ja ekologiselta kannalta. Viljelyympäristölle on ominaista ihmisen muokkaamien ja luonnontilaisten ekosysteemien kohtaaminen. Vallitseva viljelytekniikka ja yhteiskunnalliset päätökset vaikuttavat maatalousmaiseman rakenteeseen.

Tutkimuksen tarkoituksena oli kvantifioida alueen maisemanmuutosta luokiteltujen maisemaelementtien avulla. Kohteena oli yksi 324 ha kokoinen alue Toivakan kunnassa. Pellon osuus alueen maankäytöstä oli keskimäärin $17,4 \%$.

Paikkatietoanalyysin aineistona oli sarja ilmavalokuvia vuosilta 1944, 1959, 1979 ja 1991, jotka siirrettiin IDRISI ${ }^{\mathrm{TM}}$-paikkatietojärjestelmään digitointipöydän avulla. Mitattuja muuttujia olivat lineaaris- ten maisemaelementtien pituus ja aluemaisten maisemaelementtien pinta-ala. Maiseman monimuotoisuuden mittaamiseksi laskettiin monimuotoisuus-indeksit, ja peltolohkoille määritettiin lisäksi fraktaalidimensio, joka kuvaa maisemamosaiikin monitahoisuutta.

Tutkimusalueen monimuotoisuus väheni 1950luvulta lähtien. Erityisesti lineaariset maisemaelementit, kuten avo-ojat ja muut reunabiotoopit, vähenivät 876:sta 449 metriin peltohehtaaria kohden. Menetyksen keskinopeus oli 9,1 m reunabiotooppia vuotta ja hehtaaria kohden. Maisemaelementtien monimuotoisuus-indeksi laski $35 \%$. Peltolohkojen lukumäärä väheni $29 \%$, ja keskimääräinen lohkokoko kasvoi 1,2 :sta 1,7 hehtaariin eli $45 \%$. Mosaiikin monitahoisuus väheni suuntaa-antavasti fraktaalidimensiosta 1,88 (huippu 1959) 1,86:een (1991).

Viljely-ympäristön muutos heijastaa maatalouden koneistumisen ja muun tehostumisen kehitystä Suo- 
Ruuska, R. \& Helenius, J. Analysis of agricultural landscape change

messa. Alue-ekologisesti voidaan tulkita, että biotooppitason monimuotoisuus on vähentynyt (aineisto ei sisältänyt biotooppien laadun mittareita). Laajemmisssa jatkotutkimuksissa tulisi selvittää, miten osoitetun tyyppiset, hajanaiset, maatalouspolitiikkaa heijastavat ja viljelytekniikan sekä tuotantosuuntien muutosten mukanaan tuomat maisemamuutokset vai- kuttavat agroekosysteemien toimintaan ja maatalouden maankäytön ekologiseen ja kulttuuriseen kestävyyteen. Työmme osoittaa, että käytetyllä varsin yksinkertaisella ja halvalla menetelmällä saadaan sellaista kvantifioitua tietoa, jota voidaan käyttää maisemamuutosten seurannassa ja niiden vaikutusten tulkinnassa yhdessä täydentävien kenttämittausten kanssa. 